\title{
In Vivo Pharmacologic Profile of ONO-1078: A Potent, Selective and Orally Active Peptide Leukotriene (LT) Antagonist
}

\author{
Naoki Nakagawa, Takaaki Obata, Tadamasa Kobayashi, Yutaka Okada, \\ Fumio Nambu, Tamiya Terawaki and Hideki Aishita \\ Minase Research Institute, Ono Pharmaceutical Co., Ltd., 3-1-I Sakurai, Shimamoto-cho, Mishima-gun, Osaka 618, Japan \\ Received June 5, 1992 Accepted August 13, 1992
}

\begin{abstract}
We investigated the in vivo antagonistic activity of ONO-1078 against peptide lcukotrienes (LTs) in guinea pigs. ONO-1078, when administered p.o. $(0.3-3 \mathrm{mg} / \mathrm{kg})$, caused a dose-dependent reduction of $\mathrm{LTC}_{4^{-}}, \mathrm{LTD}_{4^{-}}$and $\mathrm{LTE}_{4^{-}}$induced bronchoconstriction, $\mathrm{LTD}_{4^{-}}$-induced airway microvascular leakage and $\mathrm{LTD}_{4}$-induced increase in cutaneous vascular permeability. When administered intravenously, ONO-1078 $(3-30 \mu \mathrm{g} / \mathrm{kg})$ inhibited these responses approximately $200-600$ fold more potently than FPL55712. When guinea pigs were treated with indomethacin to examine the antagonism of ONO-1078 on the direct action against peptide LTs, intravenous $(3-30 \mu \mathrm{g} / \mathrm{kg})$ and oral $(0.3-3$ $\mathrm{mg} / \mathrm{kg}$ ) administration of ONO-1078 also inhibited $\mathrm{LTC}_{4^{-}}$and $\mathrm{LTD}_{4}$-induced bronchoconstriction, and its activity was approximately $300-500$ fold more potent than that of FPL55712. ONO-1078 $(10 \mathrm{mg} / \mathrm{kg}$, i.v.) had no inhibitory effect on bronchoconstrictions induced by histamine, acetylcholine, serotonin, arachidonic acid, $\mathrm{LTB}_{4}$, prostaglandin (PG) $\mathrm{F}_{2 \alpha}, \mathrm{PGD}_{2}, 9 \alpha, 11 \beta-\mathrm{PGF}_{2}$, a stable thromboxane $\mathrm{A}_{2}$ mimetic agent and platelet activating factor. Furthermore, oral administration of ONO-1078 $(1-10 \mathrm{mg} / \mathrm{kg})$ inhibited slow-reacting substance of anaphylaxis mediated bronchoconstriction induced by antigen in a dose-dependent manner. These results indicate that ONO-1078 is an extremely potent, selective and orally active peptide LT antagonist and that oral administration of ONO-1078 antagonizes not only exogenously administered peptide LTs but also endogenous peptide LTs.
\end{abstract}

Keywords: ONO-1078, Leukotrienes (peptide) $\left(\mathrm{LTC}_{4}, \mathrm{LTD}_{4}\right.$ and $\left.\mathrm{LTE}_{4}\right)$, Bronchoconstriction, Vascular permeability, FPL55712

Peptide leukotrienes (LTs) $\mathrm{C}_{4}, \mathrm{D}_{4}$ and $\mathrm{E}_{4}$, the main components of the slow-reacting substance of anaphylaxis (SRS-A) (1-3), potently contract airway smooth muscle, induce mucus secretion and increase vascular permeability (4-7). Furthermore, they are found in the sputum, urine, bronchoalveolar lavage fluid, plasma and nasal secretions from asthmatic patients $(8-12)$. Accordingly, they have been suggested to play pathophysiological roles in asthma. Orally effective antagonists which prevent the activity of peptide LTs might be expected to be useful for the therapy of bronchial asthma. FPL55712 (sodium 7-[3-(4-acetyl-3hydroxy-2-propylphenoxy)-2-hydroxypropoxy]-4-oxo-8propyl- $4 H$-1-benzopyran-2-carboxylate) as the first peptide LT antagonist was discovered by Augstein et al. (13). However, the therapeutic potential of this compound was limited by its poor oral bioavailability and its short biological half life $(14,15)$.
Our recent efforts have focused on the design of high-affinity and orally active peptide LT antagonists from the derivatives of ( $p$-amylcinnamoyl) anthranilic acid (16). This resulted in the discovery of 4-oxo-8-[4(4-phenylbutoxy) benzoylamino]-2-(tetrazol-5-yl)-4H-1benzopyran hemihydrate (ONO-1078) (Fig. 1) as a pep-

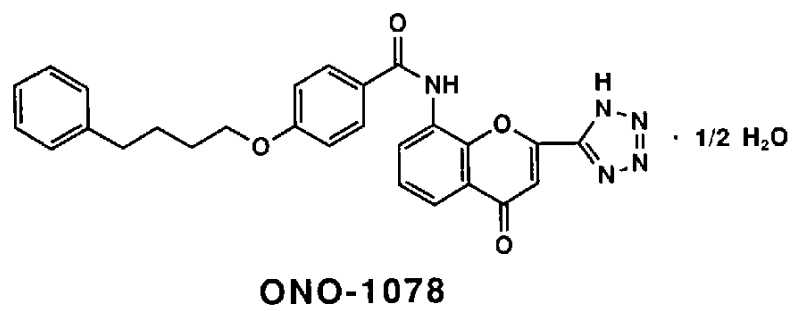

Fig. 1. Chemical structure of ONO-1078, 4-oxo-8-[4-(4-phenylbutoxy)benzoylamino]-2-(tetrazol-5-yl)-4H-1-benzopyran hemihydrate. 
tide LT antagonist. In this report, we describe the in vivo pharmacologic profile of ONO-1078.

\section{MATERIALS AND METHODS}

\section{Animals}

Male Hartley guinea pigs (Nihon Rabbit Co.), weighing 250 to $400 \mathrm{~g}$, were used throughout the experiments. Animals were housed in a temperature- and humidity-controlled room ( $12 \mathrm{hr}$ light and $12 \mathrm{hr}$ dark cycle) with free access to food and water.

\section{Chemicals}

The following drugs and chemicals were used: $\mathrm{LTE}_{4}$ (Wako Pure Chemical Co.); histamine dihydrochloride, ovalbumin (OA, grade III), indomethacin and arachidonic acid sodium salt (Sigma Chemical Co.); serotonin creatinine sulfate (Merck Co.); acetylcholine chloride (Ovisot $^{\mathbb{R}}$; Daiichi Pharmaceutical Co.); mepyramine maleate (May \& Baker Co.); killed organisms Bordetella pertussis (The Chemo-Sero-Therapeutic Research Institute); ketotifen fumarate (Zaditen ${ }^{\mathbb{R}}$; Sankyo Co.); azelastine hydrochloride (Azeptin ${ }^{\mathrm{R}}$; Eisai Co.); Evans blue (Tokyo Kasei Co.); polyoxyethyleneglycerin trioxystearic acid 40 (HCO-40) as a cationic surfactant (Nikko Chemical Co.); formamide (Katayama Chemical Co.). ONO-1078, FPL55712, $\mathrm{LTB}_{4}, \mathrm{LTC}_{4}, \mathrm{LTD}_{4}$, prostaglandin (PG) $\mathrm{F}_{2 \alpha}, \mathrm{PGD}_{2}, 9 \alpha, 11 \beta-\mathrm{PGF}_{2}$, a stable thromboxane $\mathrm{A}_{2}$ mimetic agent $\left(\mathrm{STA}_{2}\right)$ and platelet activating factor (PAF) were synthesized by Ono.

$\mathrm{LTC}_{4}, \mathrm{LTD}_{4}$ and $\mathrm{LTE}_{4}$ were dissolved in $50 \%$ ethanol, and diluted with $1 / 15 \mathrm{M}$ phosphate-buffered solution ( $\mathrm{pH}$ 7.4). For the experiment of cutaneous vascular permeability, $\mathrm{LTD}_{4}$ was diluted with $0.9 \% \mathrm{NaCl}$. Mepyramine maleate, $\mathrm{OA}$ and Evans blue were dissolved in $0.9 \% \mathrm{NaCl}$. Indomethacin was dissolved in $7 \%$ sodium bicarbonate solution. FPL55712, ketotifen fumarate and azelastine hydrochloride were dissolved in distilled water, and ONO-1078 for oral administration was suspended in $0.5 \%$ sodium carboxymethylcellulose solution. ONO-1078 for intravenous administration was initially dissolved in a solution of equimolar $1 \mathrm{~N} \mathrm{NaOH}$ and $50 \%$ ethanol, prepared to a concentration of 50 $\mathrm{mg} / \mathrm{ml}$ as a stock solution, and then diluted with $5 \%$ ethanol / $1 \% \mathrm{HCO}-40 / 0.9 \% \mathrm{NaCl}$ before use.

\section{Measurement of bronchoconstriction}

The method was essentially a modification of the Konzett-Rössler (17) technique. Guinea pigs were anesthetized with sodium pentobarbital $(75 \mathrm{mg} / \mathrm{kg}$, i.p.). A small cannula was inserted into trachea. The right jugular vein was cannulated for the administration of drugs and antigen. The tracheal cannula was connected to a constant volume respirator (Model SN-480-7 $7^{\bar{R}}$, Shinano Apparatus), and the animals were artificially ventilated with a constant volume of $5 \mathrm{ml}$ at a frequency of 70 strokes $/ \mathrm{min}$. Changes in insufflation pressure at a constant airflow were measured by a pressure transducer (MFP-1T ${ }^{\mathrm{R}}$, MFP-1100 ${ }^{\mathrm{B}}$; Nihon Kohden) connected to the side-arm of the tracheal cannula. Spasmogen- or antigen-induced bronchoconstriction was measured for 10 or $15 \mathrm{~min}$ and represented as a percentage of the maximal increase in insufflation pressure achieved by clamping-off the trachea.

\section{Spasmogen-induced bronchoconstriction}

Bronchoconstrictions were induced by intravenous administration of the spasmogens: LTC $_{4}(2 \mu \mathrm{g} / \mathrm{kg})$, $\mathrm{LTD}_{4}(2 \mu \mathrm{g} / \mathrm{kg}), \mathrm{LTE}_{4}(5 \mu \mathrm{g} / \mathrm{kg})$, histamine $(10 \mu \mathrm{g} / \mathrm{kg})$, acetylcholine $(30 \mu \mathrm{g} / \mathrm{kg})$, serotonin $(10 \mu \mathrm{g} / \mathrm{kg})$, arachidonic acid $(1000 \mu \mathrm{g} / \mathrm{kg}), \quad \mathrm{LTB}_{4} \quad(20 \mu \mathrm{g} / \mathrm{kg})$, $\mathrm{PGF}_{2 \alpha}(300 \mu \mathrm{g} / \mathrm{kg}), \quad \mathrm{PGD}_{2}(100 \mu \mathrm{g} / \mathrm{kg}), \quad 9 \alpha, 11 \beta-\mathrm{PGF}_{2}$ $(300 \mu \mathrm{g} / \mathrm{kg})$, STA $_{2}(3 \mu \mathrm{g} / \mathrm{kg})$ and PAF $(0.3 \mu \mathrm{g} / \mathrm{kg})$. Indomethacin $(2 \mathrm{mg} / \mathrm{kg})$, to eliminate the contribution of thromboxane $\mathrm{A}_{2}\left(\mathrm{TXA}_{2}\right)$ to peptide LTs-induced bronchoconstriction $(18,19)$, was administered intravenously $2 \mathrm{~min}$ before $\mathrm{LTC}_{4}$ or $\mathrm{LTD}_{4}$ challenge. ONO1078 , azelastine and ketotifen were administered orally $1 \mathrm{hr}$ before spasmogen challenge. FPL55712 and ONO1078 were administered intravenously $1 \mathrm{~min}$ before spasmogen challenge.

\section{Antigen-induced SRS-A-mediated bronchoconstriction}

Guinea pigs were actively sensitized by intraperitoneal administration $(0.5 \mathrm{ml})$ of $1 \mathrm{mg}$ OA containing 5 $\times 10^{9}$ killed organisms of Bordetella pertussis on day 0 . On days 14 to 18 , the sensitized animals were pretreated with intravenous administration of indomethacin $(2 \mathrm{mg} / \mathrm{kg})$ at $3 \mathrm{~min}$ and mepyramine $(1 \mathrm{mg} / \mathrm{kg})$ at $2 \mathrm{~min}$ before $O A$ challenge to eliminate the contribution by endogenous PGs, $\mathrm{TXA}_{2}$ and histamine, and challenged with intravenous administration of $\mathrm{OA}(0.5 \mathrm{mg} / \mathrm{kg})$. ONO-1078 was administered orally $1 \mathrm{hr}$ before OA challenge.

\section{$\mathrm{LTD}_{4}$-induced airway microvascular leakage}

Guinea pigs were anesthetized with sodium pentobarbital at the dose of $75 \mathrm{mg} / \mathrm{kg}$, intraperitoneally. A tracheal cannula was inserted and attached to a constant volume respirator (Model $\mathrm{SN}-480-7^{\bar{\AA}}$, Shinano Apparatus). Animals were respirated with a constant volume of $5 \mathrm{ml}$ at a rate of 70 strokes $/ \mathrm{min}$. A catheter was inserted into the jugular vein for the administration of $\mathrm{LTD}_{4}$ and Evans blue. One min after the administration of Evans blue $(20 \mathrm{mg} / \mathrm{kg})$, the animal was challenged with $\mathrm{LTD}_{4}(2 \mu \mathrm{g} / \mathrm{kg})$ and $10 \mathrm{~min}$ later, exsan- 
guinated. The chest cavity was opened, and Evans blue dye was washed out by perfusing with $0.9 \% \mathrm{NaCl}$ from the pulmonary artery into the left atrium. The airways and lung were then removed and cleared of extraneous connective tissues. The extrapulmonary airway was separated into trachea and main bronchi, and the intrapulmonary airways stripped of parenchyma. Wet weights of all tissues were taken. Evans blue dye was extracted by $2 \mathrm{ml}$ of formamide for more than $24 \mathrm{hr}$. The amount of Evans blue dye was determined by measuring the optical density at $620 \mathrm{~nm}$ with a spectrophotometer (UV-240 ${ }^{\mathrm{R}}$, Shimadzu) and expressed as $\mathrm{ng} / \mathrm{mg}$ tissue. The baseline was determined by the administration of $0.9 \% \mathrm{NaCl}$ containing Evans blue dye. ONO-1078 was given orally $1 \mathrm{hr}$ before $\mathrm{LTD}_{4}$ challenge.

LTD $D_{4}$-induced increase in cutaneous vascular permeability in conscious guinea pigs

The backs of guinea pigs were shaved with an electric clipper $3 \mathrm{hr}$ before the experiment. Evans blue (20 $\mathrm{mg} / \mathrm{ml}$ ) in $0.5 \mathrm{ml}$ of $0.9 \% \mathrm{NaCl}$ was administered intravenously to the guinea pigs and immediately, $\mathrm{LTD}_{4}$ $(50 \mathrm{ng} / \mathrm{site}$ ) and $0.9 \% \mathrm{NaCl}$ (to indicate the amount of vascular leakage that occurs as an injection artifact) were injected intradermally to the backs of the animals. The animals were challenged with $\mathrm{LTD}_{4}$ and $30 \mathrm{~min}$ later, exsanguinated. The dorsal skin was removed, and the site of Evans blue dye leaked was placed in $1 \mathrm{ml}$ of $1 \mathrm{~N} \mathrm{KOH}$ and incubated at $37^{\circ} \mathrm{C}$ for 16 to $20 \mathrm{hr}$. After addition of $6.5 \mathrm{ml}$ of acetone and $2.5 \mathrm{ml}$ of $0.6 \mathrm{~N}$ $\mathrm{H}_{3} \mathrm{PO}_{4}$, the mixture was vortexed and then filtered through filter paper (ADVANTEC No. 2, Toyo Roshi). The optical density of the filtrate at $620 \mathrm{~nm}$ was measured with a spectrophotometer (UV-240 ${ }^{\mathrm{B}}$, Shimadzu). The concentration of Evans blue dye leaked was calculated from a standard curve constructed with four known concentrations of Evans blue dye. ONO-1078 and FPL55712 were administered intravenously $1 \mathrm{~min}$ before $\mathrm{LTD}_{4}$ injection, and ONO-1078 for oral administration was given $1 \mathrm{hr}$ before $\mathrm{LTD}_{4}$ injection.

\section{Statistical analyses}

Results were expressed as the mean \pm standard error (S.E.). Either Student's $t$-test or two-way analysis of variance followed by Dunnett's $t$-test was used to determine statistical significance $(P<0.05)$ between means.

\section{RESULTS}

Effect of ONO-1078 on peptide LT-induced bronchoconstriction in guinea pigs

Intravenous administration of peptide LTs produced a biphasic bronchoconstriction with peaks that appeared at 30-60 sec and 4-5 min. Intravenous and oral administration of ONO-1078 inhibited $\mathrm{LTC}_{4^{-}}, \mathrm{LTD}_{4^{-}}$and LTE $_{4}$-induced bronchoconstriction in a dose-dependent manner (Figs. 2 and 3). FPL55712, when administered
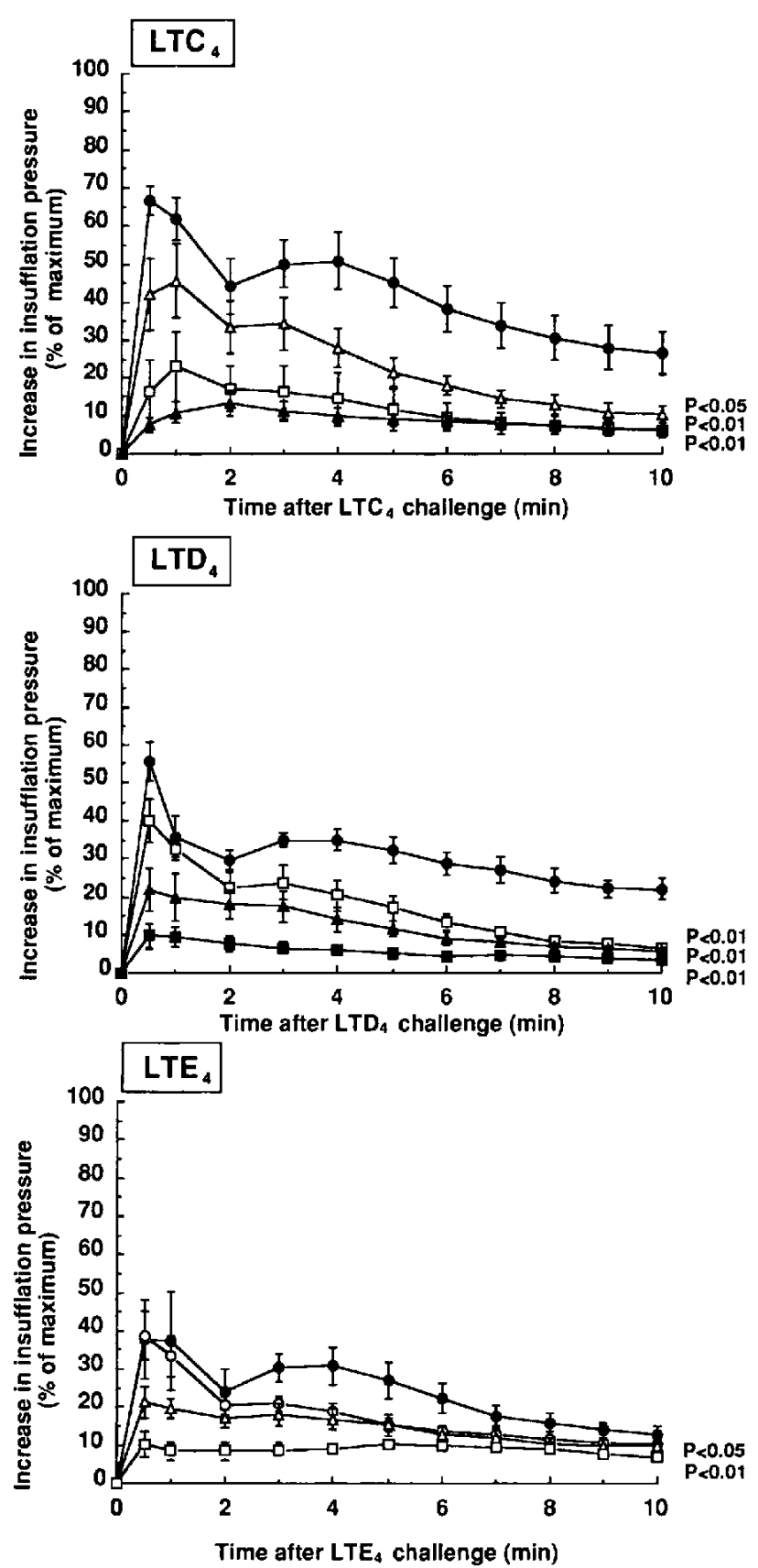

Fig. 2. Effect of ONO-1078 on $\mathrm{LTC}_{4^{-}}, \mathrm{LTD}_{4^{-}}$and $\mathrm{LTE}_{4^{-}}$-induced bronchoconstriction in guinea pigs. Vehicle (O) or ONO-1078 (○: $1 \mu \mathrm{g} / \mathrm{kg}, \triangle: 3 \mu \mathrm{g} / \mathrm{kg}, \square: 10 \mu \mathrm{g} / \mathrm{kg}, \Delta: 30 \mu \mathrm{g} / \mathrm{kg}, \square: 100$ $\mu \mathrm{g} / \mathrm{kg}$ ) was administered intravenously $1 \mathrm{~min}$ before peptide LT challenge. Each value represents the mean $\pm S$.E. of 5 animals. $P<0.05, P<0.01$ : significant difference compared to the vehicle using two-way analysis of variance followed by Dunnett's $t$-test. 
intravenously, inhibited these responses. Their $E D_{50}$ values are shown in Table 1. Significant antagonistic activity of ONO-1078 $(10 \mathrm{mg} / \mathrm{kg}$, p.o. $)$ against $\mathrm{LTD}_{4}$ lasted for $3 \mathrm{hr}$ (Fig. 4). Neither azelastine nor ketotifen inhibited $\mathrm{LTD}_{4}$-induced bronchoconstriction at 10 $\mathrm{mg} / \mathrm{kg}$, p.o. (Fig. 5 and Table 1).
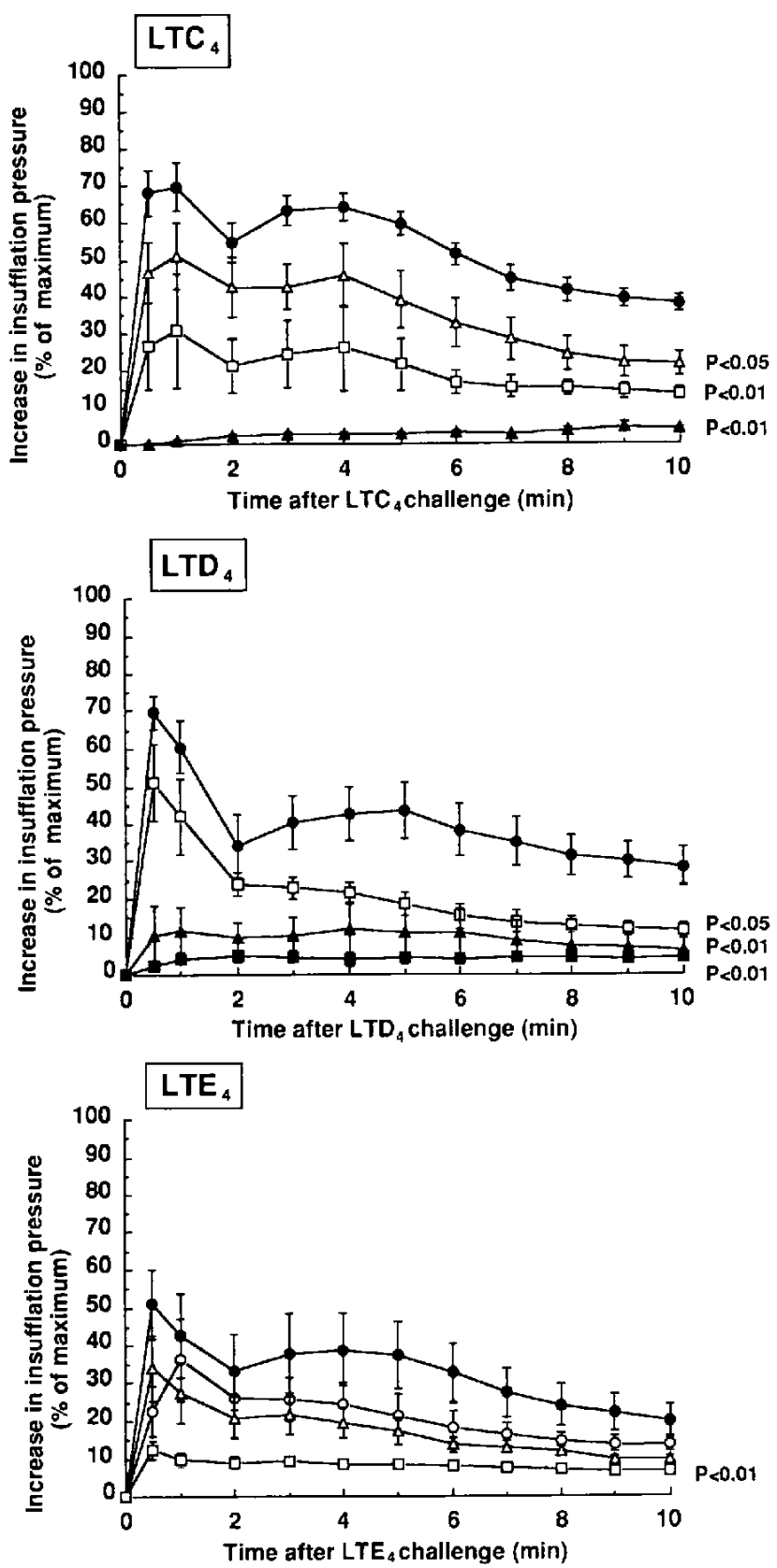

Fig. 3. Effect of ONO-1078 on $\mathrm{LTC}_{4^{-}}, \mathrm{LTD}_{4^{-}}$and $\mathrm{LTE}_{4}$-induced bronchoconstriction in guinea pigs. Vehicle (O) or ONO-1078 ( $: 0.1 \mathrm{mg} / \mathrm{kg}, \triangle: 0.3 \mathrm{mg} / \mathrm{kg}, \square: 1 \mathrm{mg} / \mathrm{kg}, \Delta: 3 \mathrm{mg} / \mathrm{kg}, \mathbf{\square}: 10$ $\mathrm{mg} / \mathrm{kg}$ ) was administered orally $1 \mathrm{hr}$ before peptide LT challenge. Each value represents the mean $\pm \mathrm{S}$.E. of 5 animals. $\mathrm{P}<0.05$, $\mathrm{P}<0.01$ : significant difference compared to the vehicle using two-way analysis of variance followed by Dunnett's $t$-test.
When guinea pigs were pretreated with indomethacin, intravenous administration of $\mathrm{LTC}_{4}$ or $\mathrm{LTD}_{4}$ produced a slowly developing but maximal bronchoconstriction; After the initial phase of this bronchoconstriction disappeared, a new peak appeared at 2 to $3 \mathrm{~min}$. Intravenous and oral administration of ONO-1078 inhibitcd both $\mathrm{LTC}_{4}$ - and $\mathrm{LTD}_{4}$-induced bronchoconstriction in a dose-dependent manner (Figs. 6 and 7). FPL55712, when administered intravenously, inhibited these responses. Their $\mathrm{ED}_{50}$ values are shown in Table 2. However, ONO-1078 (10 mg/kg, i.v.) had no effect on bronchoconstrictions induced by spasmogens other than peptide LTs (Table 3).

Table 1. Effects of ONO-1078, FPL55712, azelastine and ketotifen on $\mathrm{LTC}_{4^{-}}, \mathrm{LTD}_{4^{-}}$and $\mathrm{LTE}_{4}$-induced bronchoconstriction in guinea pigs

\begin{tabular}{lcccc}
\hline & & \multicolumn{3}{c}{$\mathrm{ED}_{50}(\mu \mathrm{g} / \mathrm{kg})$} \\
\cline { 3 - 5 } Drugs & Route & LTC $_{4}$ & LTD $_{4}$ & LTE $_{4}$ \\
\hline ONO-1078 & i.v. & 3.8 & 15.8 & 4.8 \\
FPL55712 & i.v. & 1440 & 2650 & 1040 \\
ONO-1078 & p.o. & 590 & 970 & 270 \\
Azelastine & p.o. & ND & NE at $10 \mathrm{mg} / \mathrm{kg}$ & ND \\
Ketotifen & p.o. & ND & NE at $10 \mathrm{mg} / \mathrm{kg}$ & ND \\
\hline
\end{tabular}

$\mathrm{NE}=$ No effect, $\mathrm{ND}=$ Not done. The $\mathrm{ED}_{50}$ value was calculated by linear regression analysis of a plot of $\log$ drug dose versus the percent inhibition of the area under the curve of the bronchoconstriction response of the treated animals as compared with the vehicle-treated controls.

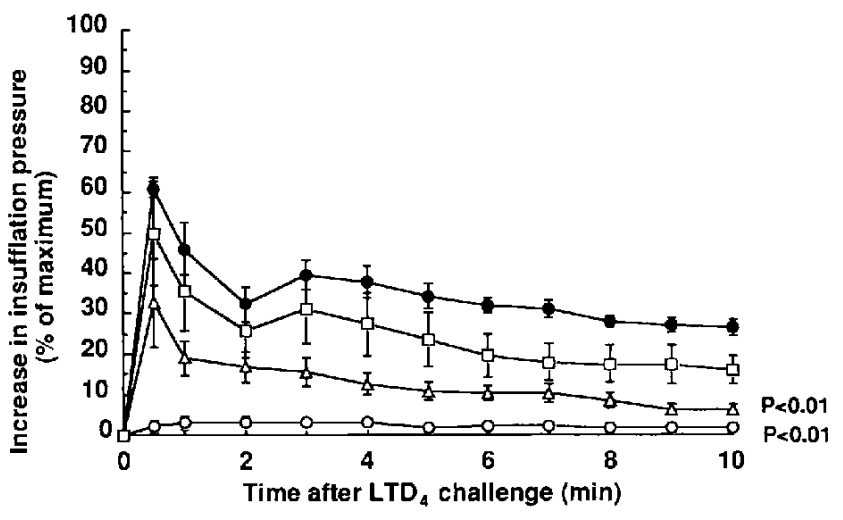

Fig. 4. Duration of inhibitory effect of orally administered ONO-1078 on $\mathrm{LTD}_{4}$-induced bronchoconstriction in guinea pigs. ONO-1078 was administered orally at a dose of $10 \mathrm{mg} / \mathrm{kg} 1 \mathrm{hr}$ $(\bigcirc), 3 \mathrm{hr}(\triangle)$ or $5 \mathrm{hr}(\square)$ before $\mathrm{LTD}_{4}$ challenge. Each value represents the mean $\pm S$.E. of 5 animals. $P<0.01$ : significant difference compared to the vehicle (O) using two-way analysis of variance followed by Dunnett's $t$-test. 


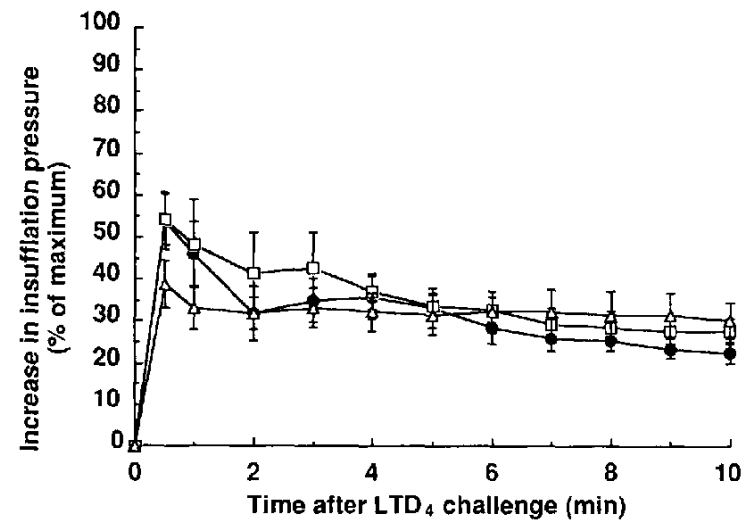

Fig. 5. Effects of ketotifen and azelastine on LTD $_{4}$-induced bronchoconstriction in guinea pigs. Vehicle $(\boldsymbol{O})$, ketotifen $(\triangle: 10$ $\mathrm{mg} / \mathrm{kg}$ ) or azelastine $(\square: 10 \mathrm{mg} / \mathrm{kg}$ ) was administered orally $1 \mathrm{hr}$ before $\mathrm{LTD}_{4}$ challenge. Each value represents the mean \pm S.E. of 5 animals.
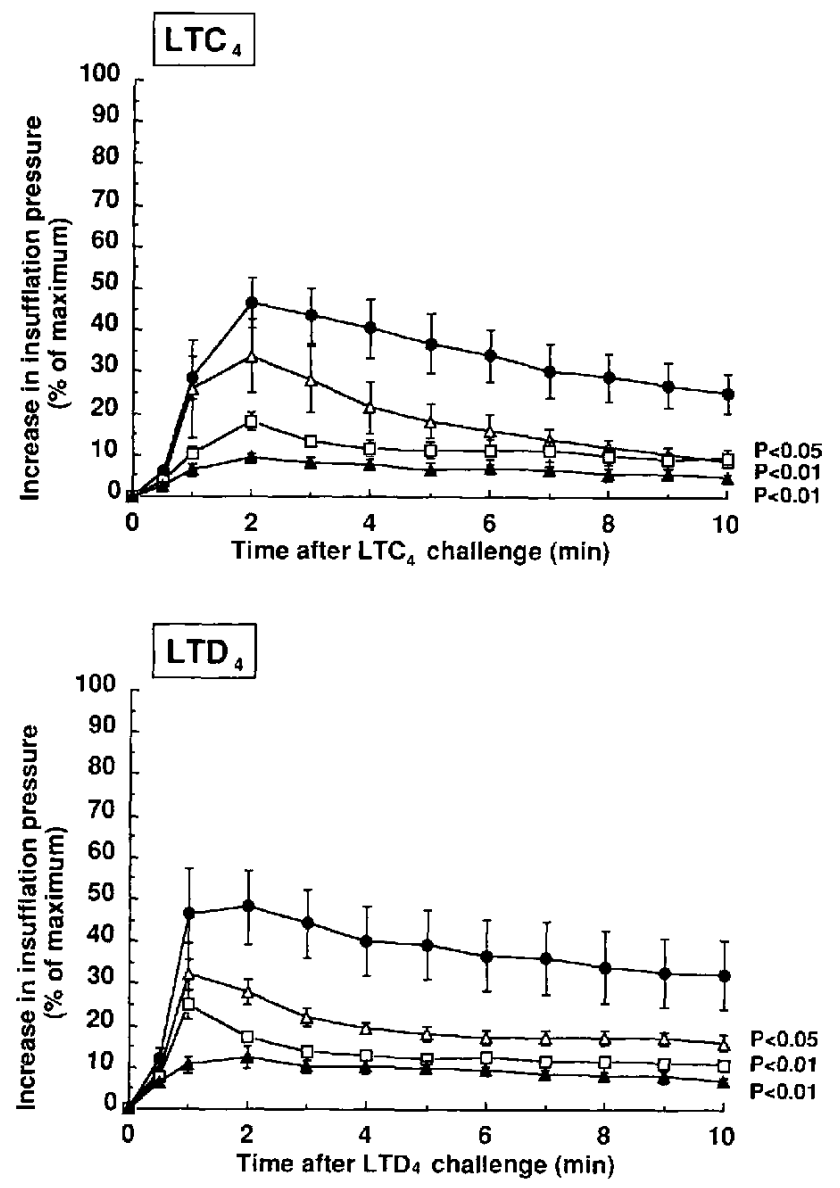

Fig. 6. Effect of $\mathrm{ONO}^{-1078}$ on $\mathrm{LTC}_{4^{-}}$and $\mathrm{LTD}_{4}$-induced bronchoconstriction in indomethacin $(2 \mathrm{mg} / \mathrm{kg}$, i.v. )-treated guinea pigs. Vehicle ( ) or ONO-1078 ( $\triangle: 3 \mu \mathrm{g} / \mathrm{kg}, \square: 10 \mu \mathrm{g} / \mathrm{kg}$, $30 \mu \mathrm{g} / \mathrm{kg}$ ) was administered intravenously $1 \mathrm{~min}$ before peptide LT challenge, and indomethacin was administered intravenously 2 min before peptide LT challenge. Each value represents the mean \pm S.E. of 5 animals. $P<0.05, P<0.01$ : significant difference compared to the vchicle using two-way analysis of variance followed by Dunnett's $t$-test.
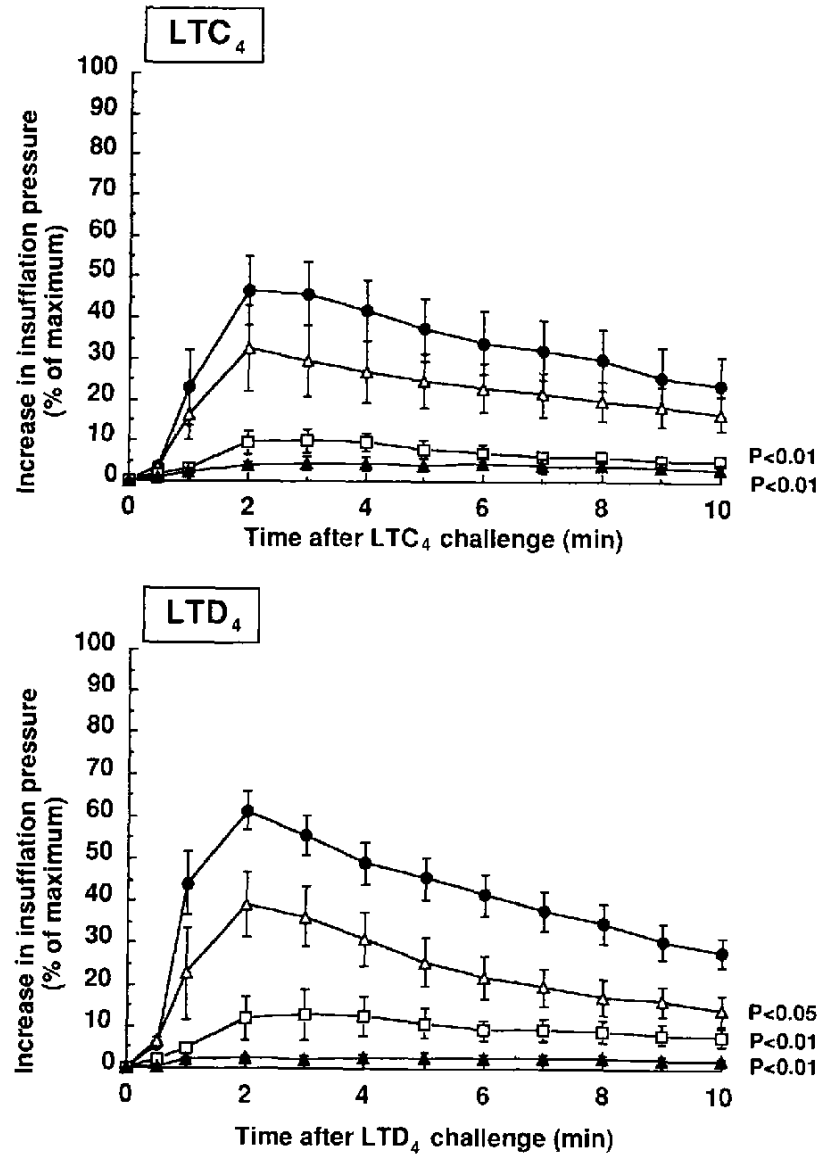

Fig. 7. Effect of ONO-1078 on $\mathrm{LTC}_{4}$ - and LTD $\mathrm{LT}_{4}$-induced bronchoconstriction in indomethacin $(2 \mathrm{mg} / \mathrm{kg}$, i.v. $)$-treated guinea pigs. Vehicle (O) or ONO-1078 ( $\triangle: 0.3 \mathrm{mg} / \mathrm{kg}, \square: 1 \mathrm{mg} / \mathrm{kg}, \mathbf{\Delta}$ : $3 \mathrm{mg} / \mathrm{kg}$ ) was administered orally $1 \mathrm{hr}$ before peptide LT challenge, and indomethacin was administered intravenously $2 \mathrm{~min}$ before peptide $L T$ challenge. Each value represents the mean \pm S.E. of 5 animals. $P<0.05, P<0.01$ : significant difference compared to the vehicle using two-way analysis of variance followed by Dunnett's $t$-test.

Table 2. Effects of ONO-1078 and FPL55712 on LTC $_{4^{-}}$and LTD $_{4}$-induced bronchoconstriction in indomethacin-treated guinea pigs

\begin{tabular}{|c|c|c|c|}
\hline \multirow{2}{*}{ Drugs } & \multirow{2}{*}{ Routc } & \multicolumn{2}{|c|}{$\mathrm{ED}_{50}(\mu \mathrm{g} / \mathrm{kg})$} \\
\hline & & $\mathrm{LTC}_{4}$ & $\mathrm{LTD}_{4}$ \\
\hline ONO-1078 & i.v. & 4.0 & 3.4 \\
\hline FPL55712 & i.v. & 1340 & 1730 \\
\hline ONO-1078 & p.o. & 490 & 380 \\
\hline
\end{tabular}

The $\mathrm{ED}_{50}$ value was calculated by linear regression analysis of a plot of log drug dose versus the percent inhibition of the area under the curve of the bronchoconstriction response of the treated animals as compared with the vehicle-treated controls. 
Table 3. Effect of ONO-1078 on various spasmogen-induced bronchoconstrictions in guinea pigs

\begin{tabular}{lccccc}
\hline Spasmogens & $\begin{array}{c}\text { Doses of } \\
\text { spasmogens } \\
(\mu \mathrm{g} / \mathrm{kg}, \mathrm{i} . \mathrm{v} .)\end{array}$ & $\begin{array}{c}\text { Dose of } \\
\text { ONO-1078 } \\
(\mathrm{mg} / \mathrm{kg}, \mathrm{i} . \mathrm{v} .)\end{array}$ & $\mathrm{N}$ & \multicolumn{2}{c}{$\begin{array}{c}\text { Increase in insufflation pressure } \\
\text { (the maximal response, \%) } \\
\text { Vehicle }\end{array}$} \\
Histamine & 10 & 10 & 3 & $63.6 \pm 5.0$ & $66.4 \pm 1.7$ \\
Acetylcholine & 30 & 10 & 3 & $50.6 \pm 5.6$ & $49.8 \pm 5.4$ \\
Serotonin & 10 & 10 & 3 & $59.0 \pm 6.3$ & $60.0 \pm 7.8$ \\
Arachidonic acid & 1000 & 10 & 5 & $71.4 \pm 5.0$ & $66.3 \pm 6.7$ \\
LTB $_{4}$ & 20 & 10 & 3 & $55.7 \pm 17.6$ & $53.7 \pm 6.1$ \\
PGF $_{2} \alpha$ & 300 & 10 & 3 & $50.4 \pm 2.1$ & $58.7 \pm 7.8$ \\
PGD $_{2}$ & 100 & 10 & 3 & $53.4 \pm 6.0$ & $53.3 \pm 17.3$ \\
$9 \alpha, 11 \beta-\mathrm{PGF}_{2}$ & 300 & 10 & 3 & $63.6 \pm 3.9$ & $58.1 \pm 18.7$ \\
STA $_{2}$ & 3 & 10 & 5 & $47.9 \pm 3.1$ & $43.8 \pm 3.8$ \\
PAF & 0.3 & 10 & 5 & $72.6 \pm 8.4$ & $69.9 \pm 3.7$ \\
\hline
\end{tabular}

ONO-1078 was administered intravenously 1 min before injection of each spasmogen. $\mathrm{N}=\mathrm{Num}$ ber of animals. Each value represents the mean $\pm \mathrm{S}$.E. Significant difference compared to the vehicle was determined using Student's unpaired $t$-test for arachidonic acid, $\mathrm{LTB}_{4}, \mathrm{PGF}_{2 \alpha}, \mathrm{PGD}_{2}$, $9 \alpha, 11 \beta-\mathrm{PGF}_{2}$ and PAF or the paired $t$-test for histamine, acetylcholine, serotonin and STA $\mathrm{A}_{2}$.

Effect of ONO-1078 on SRS-A-mediated bronchoconstriction induced by antigen in actively sensitized guinea pigs

When actively sensitized guinea pigs were pretreated with indomethacin and mepyramine, intravenous administration of $\mathrm{OA}$ produced a typical anaphylactic bronchoconstriction which peaked at $7 \mathrm{~min}$. Oral administration of ONO-1078 inhibited this response in a dosedependent manner (Fig. 8). The $\mathrm{ED}_{50}$ value was 1.63 $\mathrm{mg} / \mathrm{kg}$.

Inhibition of $\mathrm{LTD}_{4}$-induced airway microvascular leakage in guinea pigs by $\mathrm{ONO}-1078$

$\mathrm{LTD}_{4}$ produced significant airway microvascular leakage into the trachea, main bronchi and intrapulmonary airways. ONO-1078 significantly inhibited this response in the trachea at $3 \mathrm{mg} / \mathrm{kg}$, p.o. and in the main bronchi and intrapulmonary airways, at $1-3 \mathrm{mg} / \mathrm{kg}$, p.o. (Fig. 9); the respective $\mathrm{ED}_{50}$ values of $\mathrm{ONO}-1078$ were 0.74 , 0.40 and $0.69 \mathrm{mg} / \mathrm{kg}$.

Inhibition of $L T D_{4}$-induced increase in cutaneous vascular permeability in guinea pigs by $\mathrm{ONO}-1078$

LTD $_{4}$ produced a marked increase in cutaneous vascular permeability. Oral and intravenous administration of ONO-1078 inhibited this response in a dosedependent manner. FPL55712, when administered intravenously, inhibited this response in a dose-dependent manner (Fig. 10). The $\mathrm{ED}_{50}$ values of ONO-1078 for oral and intravenous administration were $0.63 \mathrm{mg} / \mathrm{kg}$ and $10 \mu \mathrm{g} / \mathrm{kg}$, respectively, and the $\mathrm{ED}_{50}$ value of FPL55712 for intravenous administration was 5700 $\mu \mathrm{g} / \mathrm{kg}$.

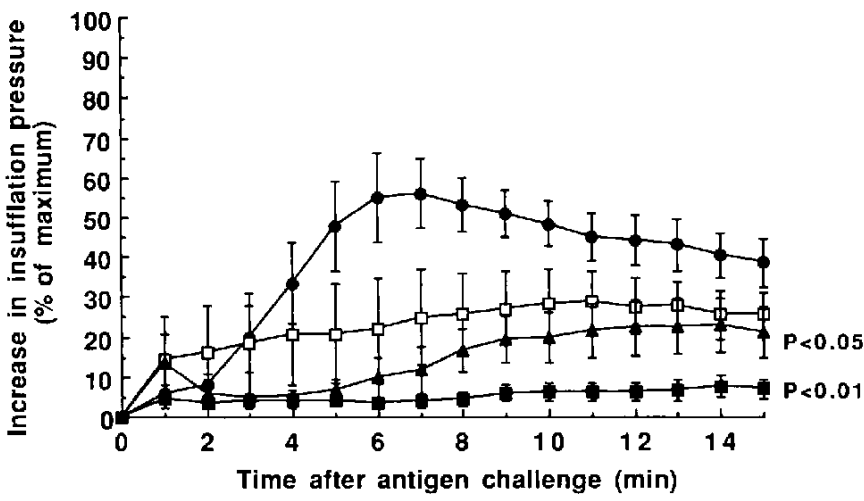

Fig. 8. Effect of ONO-1078 on antigen-induced SRS-A-mediated bronchoconstriction in guinea pigs. Vehicle (O) or ONO-1078 ( $\square: 1 \mathrm{mg} / \mathrm{kg}, \boldsymbol{\Delta}: 3 \mathrm{mg} / \mathrm{kg}, \mathbf{\square}: 10 \mathrm{mg} / \mathrm{kg}$ ) was administered orally $1 \mathrm{hr}$ before antigen challenge. Each value represents the mean \pm S.E. of $5-7$ animals. $P<0.05, P<0.01$ : significant difference compared to the vehicle using two-way analysis of variance followed by Dunnett's $t$-test. The $E_{50}$ value was calculated by linear regression analysis of a plot of log drug dose versus the percent inhibition of area under the curve of the bronchoconstriction response of the treated animals as compared with the vehicletreated controls. 

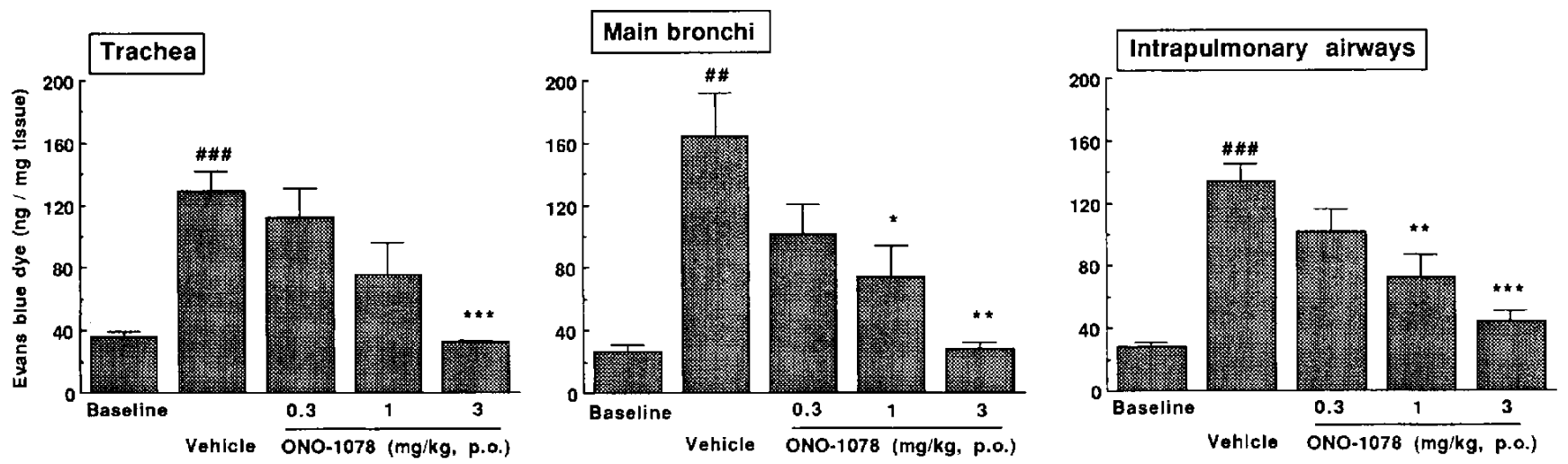

Fig. 9. Effect of ONO-1078 on airway microvascular leakage into trachea, main bronchi and intrapulmonary airways induced by $\mathrm{LTD}_{4}$ in guinea pigs. Each value represents the mean $\pm \mathrm{S}$.E. of 5 animals. ${ }^{*} \mathrm{P}<0.05,{ }^{*} \mathrm{P}<0.01,{ }^{* * *} \mathrm{P}<$ 0.001: significant difference compared to the vehicle using Student's unpaired $t$-test. $\# \mathrm{P}<0.01$, \#\# $\mathrm{P}<0.001$ : significant difference compared to the bascline value using Student's unpaired $t$-test. The ED $_{50}$ value was calculated by linear regression analysis of a plot of $\log$ drug dose versus the percent inhibition of airway microvascular leakage of the treated animals as compared with the vehicle-treated controls.
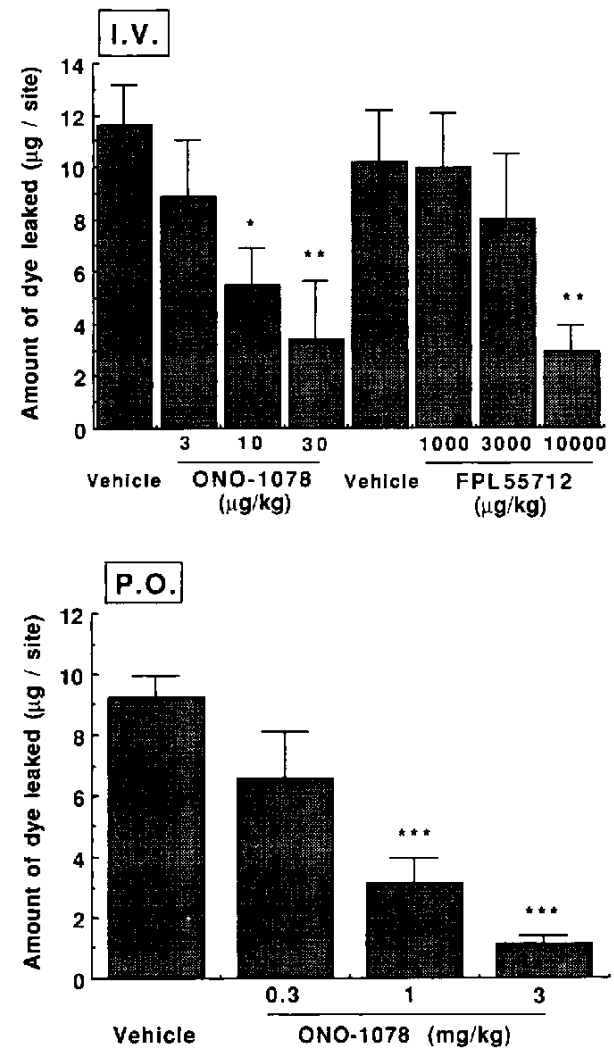

Fig. 10. Effects of ONO-1078 (i.v. and p.o.) and FPL55712 (i.v.) on the increased cutaneous vascular permeability induced by $\mathrm{LTD}_{4}$ in guinea pigs. Each value represents the mean \pm S.E. of 4- 10 animals. ${ }^{*} \mathrm{P}<0.05,{ }^{* *} \mathrm{P}<0.02,{ }^{* * *} \mathrm{P}<0.001$ : significant difference compared to the vehicle using Student's unpaired t-test. The $\mathrm{ED}_{50}$ value was calculated by lincar regression analysis of a plot of log drug dose versus the percent inhibition of increased cutaneous vascular permeability of the treated animals as compared with the vehicle-treated controls.

\section{DISCUSSION}

The present study showed that ONO-1078 was orally effective against peptide LT, and it did not antagonize the activity of spasmogens other than peptide LT. The antagonistic activity of ONO-1078 against peptide LTs were approximately $200-400$ fold more potent than that of FPL55712. These results demonstrate that ONO-1078 is a potent, selective and orally active peptide LT antagonist. Neither azelastine nor ketotifen as anti-allergic agents inhibited $\mathrm{LTD}_{4}$-induced bronchoconstriction, although in particular, azelastine has been reported to possess peptide LT antagonistic activity in vitro (20) and in vivo (21).

It has been reported that $\mathrm{TXA}_{2}$ contributes to the bronchoconstriction induced by intravenous administration of peptide LTs $(18,22-26)$. In the present study, bronchoconstriction induced by $\mathrm{LTC}_{4}(2 \mu \mathrm{g} / \mathrm{kg})$ or $\mathrm{LTD}_{4}(2 \mu \mathrm{g} / \mathrm{kg})$ was blocked only at the initial phase by indomethacin as a cyclooxygenase inhibitor. It is speculated that the initial phase of this bronchoconstriction is contributed to $\mathrm{TXA}_{2}$. Among the reports described above, it has been shown that bronchoconstriction induced by a low concentration of peptide LT $(0.5$ $\mu \mathrm{g} / \mathrm{kg})$ is mostly inhibited by indomethacin $(24,25)$. On the other hand, it has been reported that bronchoconstriction at higher concentrations of peptide LT ( > $0.8 \mu \mathrm{g} / \mathrm{kg}$ ) is only partially blocked by indomethacin $(18,23,26)$. Therefore, it is suggested that bronchoconstrictions at a higher concentration of peptide LT (2 $\mu \mathrm{g} / \mathrm{kg}$ ) were induced by both the direct action of pep-

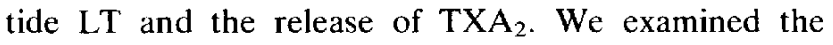
antagonism of ONO-1078 on the direct action against peptide LTs in guinea pigs pretreated with indometh- 
acin. ONO-1078 also inhibited $\mathrm{LTC}_{4^{-}}$and $\mathrm{LTD}_{4}$-induced bronchoconstriction in the pretreatment with indomethacin approximately 300 - to 500 -fold more potently than FPL55712. Therefore, these results suggest that ONO1078 has an antagonistic activity against the dircct action of peptide LTs. The $\mathrm{ED}_{50}$ value of ONO-1078 against $\mathrm{LTD}_{4}$-induced bronchoconstriction was higher than that against $\mathrm{LTC}_{4}$-induced response in non-treated animals, in spite of almost the same respective $E D_{50}$ values in indomethacin-treated animals. Since ONO1078 had no effect on the direct bronchoconstriction induced by $\mathrm{TXA}_{2}$, this difference of $E D_{50}$ value may be due to the magnitude of the contribution of the indirect action by $\mathrm{TXA}_{2}$ to $\mathrm{LTD}_{4}$-induced bronchoconstriction in non-treated animals. This is currently under investigation in our laboratories.

We examined the effect of ONO-1078 on antigeninduced bronchoconstriction in actively sensitized guinea pig in the presence of indomethacin and mepyramine to eliminate any contribution by endogenous $\mathrm{PGs}, \mathrm{TXA}_{2}$ and histamine. Since it has been reported that both $\mathrm{BW} \mathrm{A} 4 \mathrm{C}$, a 5-lipoxygenase inhibitor, and FPL55712 inhibited anaphylactic bronchoconstriction in guinea pigs pretreated with indomethacin and mepyramine (27), SRS-A is one of the main mediators of anaphylactic bronchoconstriction in this widely used model of "asthma" $(28-30)$. From the fact that ONO$1078(3-10 \mathrm{mg} / \mathrm{kg}$, p.o.) significantly inhibited SRS-Amediated bronchoconstriction, it is suggested that ONO1078 antagonizes the endogenous peptide LT response in addition to exogenous peptide LT

Peptide LT possesses the ability to increase vascular permeability in airways and skin $(31,32)$. Airway microvascular leakage is a primary feature of inflammation and leads to the formation of mucosal edema, followed by bronchial narrowing. ONO-1078 significantly inhibited LTD $_{4}$-induced microvascular leakage into all airway levels. These results suggest that the inhibition of airway microvascular leakage by ONO-1078 may contribute to the relief of antigen-induced bronchoconstriction. Since $\mathrm{LTD}_{4}$-induced increase in cutaneous vascular permeability has been reported to be independent of the rclease of histamine, serotonin or products of the cyclooxygenase pathway of arachidonic acid metabolism (31), it appears that it is mediated by the direct action of $\mathrm{LTD}_{4}$. ONO-1078 also inhibited the $\mathrm{LTD}_{4}$-induced increase in cutaneous vascular permeability, and the antagonistic activity of ONO-1078 against this response was approximately 570-fold more potent than that of FPL55712. This result suggests that ONO-1078 potently antagonizes the direct action against LTD $_{4}$.

In conclusion, ONO-1078 is a highly potent, selective and orally active peptide LT antagonist in vivo. Further- more, ONO-1078 antagonizes not only exogenous peptide LT but also endogenous peptide LT. Therefore, it is suggested that ONO-1078 may be useful for the therapy of allergic and inflammatory diseases such as bronchial asthma to which peptide LT is greatly related.

\section{REFERENCES}

1 Murphy, R.C., Hammarstöm, S. and Samuelsson, B.: Lcukotriene $\mathrm{C}_{4}$, a slow reacting substance (SRS) from mouse mastocytoma cells. Proc. Natl. Acad. Sci. U.S.A. 76, 42754279 (1979)

2 Morris, H.R., Taylor, G.W., Piper, P.J., Samhoun, M.N. and Tippins, J.R.: The structure identification of SRS from rat basophilic leukemia (RBL-1) cells. Prostaglandins 19, $185-201$ (1980)

3 Lewis, R.A., Austen, K.F., Drazen, J.M., Clark, D.A., Marfat, A. and Corey, E.J.: Slow reacting substances of anaphylaxis: Identification of leukotrienes C-1 and D from human and rat sources. Proc. Natl. Acad. Sci. U.S.A. 77, $3710-3714(1980)$

4 Samuelsson, B.: Leukotrienes: Mediators of immediate hypersensitivity reactions and inflammation. Science 220, $568-575$ (1983)

5 Drazen, J.M., Austen, K.F., Lewis, R.A., Clark, D.A., Goto, G., Marfat, A. and Corey, E.J.: Comparative airway and vascular activities of leukotrienes $C-1$ and $D$ in vivo and in vitro. Proc. Natl. Acad. Sci. U.S.A. 77, 4354-4358 (1980)

6 Marom, Z., Shelharmer, J.H., Bach, M.K., Morton, D.R. and Kaliner, M.: Slow-reacting substances of anaphylaxis, leukotrienes $\mathrm{C}_{4}$ and $\mathrm{D}_{4}$ increase the release of mucus from human airways in vitro. Am. Rev. Respir. Dis. 126, 449-451 (1982)

7 Peck, M.J., Piper, P.J. and Williams, T.J.: The effects of leukotrienes $\mathrm{C}_{4}$ and $\mathrm{D}_{4}$ on the microvasculature of guinea pigs. Prostaglandins 21, 315-321 (1981)

8 Wardlaw, A.J., Hay, H., Cromwell, O., Collins, J.W. and Kay, A.B.: Leukotrienes, $\mathbf{L T C}_{4}$ and $\mathrm{B}_{4}$ in bronchoalveolar lavage in bronchial asthma and respiratory diseases. $J$. Allergy Clin. Immunol. 84, 19-26 (1989)

9 Lam, S., Cham, H., LeRiche, J.C., Chan-Yeung, M. and Salari, H.: Release of leukotrienes in patients with bronchial asthma. J. Allergy Clin. Immunol. 81, $1711-1717$ (1988)

10 Taylor, G.W., Taylor, I., Black, P., Maltby. N.H.. Turner, N., Fuller, R.W. and Dollery, C.T.: Urinary leukotriene $\mathbf{E}_{4}$ after antigen challenge in acutc asthma and in allergic rhinitis. Lancet 1, 584-588 (1989)

11 Okubo, T., Takahashi, H., Sumitano, M., Shimdoh, K. and Suzuki, S.: Plasma levels of leukotrienes $C_{4}$ and $D_{4}$ during wheezing attack in asthmatic patients. Int. Arch. Allergy Appl. Immunol. 84, 149-155 (1987)

12 Ferreri, N.R., Howland, W.C., Stevenson, D.D. and Spiegelberg, H.L.: Release of leukotrienes, prostaglandins and histamine into nasal secretion of aspirin-sensitive asthmatics during reaction to aspirin. Am. Rev. Respir. Dis. 137, $847-854$ (1988)

13 Augstein, J., Farmer, J.B., Lee, T.B., Sheard, P. and Tattersall, M.L.: Selective inhibitor of slow reacting substance of anaphylaxis. Nature New Biol. 245, $215-216$ (1973) 
14 Sheard, P., Lee, T.B. and Tattersall, M.L.: Further studies on the SRS-A antagonist FPL-55712. Monogr. Allergy 12, $245-249$ (1977)

15 Sheard, P., Holroyde, M.C., Bantick, J.R. and Lee, T.B.: SRS-A antagonists. In Development of Anti-Asthma Drugs, Edited by Buckle, D.B., p. 133-158, Butterworth, London (1984)

16 Nakai, H., Konno, M., Kosuge, S., Sakuyama, S., Toda, M., Arai, Y., Obata, T., Katsube, N., Miyamoto, T., Okegawa. T. and Kawasaki, A.: New potent antagonists of leukotrienes $\mathrm{C}_{4}$ and $\mathrm{D}_{4}$. 1. Synthesis and structure-activity relationships. J. Med. Chem. 31, 84-91 (1988)

17 Konzett, H. and Rössler, R.: Versuchsanordnung zu untersuchungen an der Bronchialmuskulatur. Arch. Exp. Pathol. Pharmakol. 195, 71-74 (1940) (in German)

18 Hamel, R., Masson, P., Ford-Hutchinson, A.W., Jones, T.R., Brunet, G. and Piechuta, H.: Differing mechanisms for leukotriene $\mathrm{D}_{4}$-induced bronchoconstriction in guinea pigs following intravenous and aerosol administration. Prostaglandins 24, 419-432 (1982)

19 Piper, P.J. and Samhoun, M.N.: Stimulation of arachidonic acid metabolism and generation of thromboxanc $\mathrm{A}_{2}$ by leukotrienes $\mathrm{B}_{4}, \mathrm{C}_{4}$ and $\mathrm{D}_{4}$ in guinea pig lung in vitro. $\mathrm{Br}$. $\mathrm{J}$. Pharmacol. 77, 267-275 (1982)

20 Chand, N.. Diamantis, W. and Sofia, R.D.: Antagonism of histamine and leukotrienes by azelastine in isolated guinea pig ileum. Agents Actions 19, $164-168$ (1986)

21 Chand, N., Nolan, K., Diamantis, W., Perhach, J.L., Jr. and Sofia, R.D.: Inhibition of leukotriene (SRS-A)-mediated acute lung anaphylaxis by azelastine in guinea pigs. Allergy 41, 473-478 (1986)

22 Weichman, B.M., Muccitelli, R.M., Osborn, R.R., Holden, D.A., Gleason, J.G. and Wasserman, M.A.: In vitro and in vivo mechanisms of leukotriene-mediated bronchoconstriction in the guinea pig. J. Pharmacol. Exp. Ther, 222, 202-208 (1982)

23 Nambu, F., Motoishi, M., Omawari, N., Okegawa, T., Kawasaki, A. and Ikeda, S.: Inhibitory effects of OKY-046 on spasmogen-induced bronchoconstrictions in sensitized and non-sensitized guinea pigs. Japan. J. Pharmacol. 52, 307-317 (1990)

24 Piper, P.J., Samhoun, M.N., Tippins, J.R., Williams, T.J., Palmer, M.A. and Peck, M.J.: Pharmacological studies on pure SRS-A, and synthetic leukotrienes $\mathrm{C}_{4}$ and $\mathrm{D}_{4}$. In SRS-A and Leukotriencs, Edited by Piper, P.J., p. 81 -99, Research Studies Press, Letchworth (1981)

25 Ueno, A., Tanaka, K. and Katori, M.: Possible involvement of thromboxane in bronchoconstrictive and hypertensive effects of $\mathrm{LTC}_{4}$ and $\mathrm{LTD}_{4}$ in guinea pigs. Prostaglandins 23, $865-880(1982)$

26 Dahlen, S.-E.: The significance of liberated cyclooxygenase products for the pulmonary and cardiovascular actions of leukotrienes $\mathrm{C}_{4}$ in the guinea pig depends upon the route of administration. Acta Physiol. Scand. 118, 415-421 (1983)

27 Payne, A.N., Garland, L.G., Lees, I.W. and Salmon, J.A.: Selective inhibition of arachidonate 5-lipoxygenase by novel acetohydroxamic acids: effects on bronchial anaphylaxis in anaesthetized guinea-pigs. Br. J. Pharmacol. 94, 540-546 (1988)

28 Ritchie, D.M., Sierchio, J.N., Capetola, R.J. and Rosenthalc, M:E.: SRS-A-mediated bronchospasm by pharmacologic modification of lung anaphylaxis in vivo. Agents Actions 11, 396-401 (1981)

29 Anderson, W.H., O'donnell, M., Simko, B.A. and Welton, A.F.: An in vivo model for measuring antigen-induced SRSA-mediated bronchoconstriction and plasma SRS-A levels in the guinea pig. Br. J. Pharmacol. 78, 67-74 (1983)

30 Fleisch, J.H., Haisch, K.D., Spaethe, S.M., Rinkema, L.E. Cullinan, G.J., Schmidt, M.J. and Marshall, W.S.: Pharmacologic analysis of two novel inhibitors of leukotriene (slowreacting substance) release. J. Pharmacol. Exp. Ther. 229. $681-689$ (1984)

31 Rinkema, L.E., Bemis, K.G. and Fleisch, J.H.: Production and antagonism of cutaneous vascular permeability in the guinea pig in response to histamine, leukotrienes and A23187. J. Pharmacol. Exp. Ther. 230, 550-557 (1984)

32 Chung, K.F.: Role of inflammation in the hyperreactivity of the airways in asthma. Thorax 41, 657-662 (1986) 